\title{
Tree Pulling Tests of Large Shade Trees in the Genus Acer
}

\author{
Brian Kane and Peggi Clouston
}

\begin{abstract}
Shade trees provide many benefits but can cause damage if they fail. Despite the potential for costly litigation that sometimes arises when damage occurs, there are no investigations of bending moments and stresses involved in failure of shade trees. Twenty-four shade trees of three species in the genus Acer were pulled to failure at a suburban property in Massachusetts, U.S. The maximum load and distance to failure were used to calculate maximum bending moment; stress at the point of failure was calculated from bending moment and stem cross-sectional dimensions. No trees uprooted, and failures were categorized as either stem at a lateral branch(es) or the attachment of codominant stems. Failures of codominant stems required one-half of the stress of stem failures. Similarly, failures of codominant stems occurred at only $45 \%$ of wood strength, whereas stem failures occurred at $79 \%$ of wood strength. Prediction of maximum bending moment from tree morphometric data was more reliable than prediction of maximum stress from tree morphometric data. Prediction of maximum bending moment and stress was more reliable for stem failures than codominant failures. Results are compared with similar tests on conifers. Implications of findings are discussed with respect to risk assessment of shade trees.
\end{abstract}

Key Words. Codominant stems; tree failure; tree pulling; trunk stress.

Shade trees are an important part of communities because they provide many diverse benefits (Nowak and Dwyer 2000). Large shade trees provide greater environmental benefits than smaller trees (Nowak et al. 2002), but large trees can also provide a greater degree of risk. As trees mature, structural defects often necessitate tree removal for safety reasons. Assessing the risk of failure of shade trees has been hampered by a lack of empiric data, especially with respect to assessment of structural defects. Existing studies entail observations of failed and standing trees after storms (Cutler et al. 1990; Gibbs and Greig 1990; Smiley and Fraedrich 1992; Duryea et al. 1996; Jim and Liu 1997; Francis 2000) Without empiric data, practitioners face the dilemma of deciding whether to remove a tree, balancing the benefits provided with the liability sometimes associated with failure (Mortimer and Kane 2004).

There are many reports of applying a load with a winch to pull forest trees (almost exclusively conifers) until they uprooted or the stem failed (Fraser 1962; Fraser and Gardiner 1967; Somerville 1979; Smith et al. 1987; Fredericksen et al. 1993; Papesch et al. 1997; Moore 2000; Peltola et al. 2000). Such studies have explored many aspects of tree failure such as which tree morphometric data best predict the critical turning or bending moment to cause failure and the effect of soil type and silvicultural practices on the probability of stem or root failure. Peltola (2006) reviewed the literature and described how data from the studies have been used to develop models to predict tree failure (e.g., Peltola et al. 1999; Gardiner et al. 2000; Ancelin et al. 2004). Although the basic mechanical principles (such as determination of drag, bending moment, and stress) should apply equally well to forest or shade trees, it is not clear that results from forest conifers can be extrapolated to shade trees.

Shade trees display an obviously different structure from forest trees. In particular, crowns tend to be taller and wider, trunks are less slender, and branches are larger relative to the size of the trunk. Shade trees often develop codominant stems, which develop when the trunk divides into two stems of approximately equal size. Often, the attachment between the stems makes a narrow angle, forming a "v-shape" in which bark occlusion occurs. Codominant stems are a common defect of shade trees (Gibbs and Greig 1990; Jim and Liu 1997), particularly among maples (Terho and Hallaksela 2005). Previous tree-pulling studies have often excluded trees with defects (Smith et al. 1987; Fredericksen et al. 1993; Meunier et al. 2002), but for shade trees, defects are common and quite relevant when assessing the risk of failure (Gibbs and Greig 1990; Terho and Hallaksela 2005).

The main objective of this study was to provide baseline data pertinent to failure of large shade trees. Of particular interest were: 1) which tree morphometric data best predict the maximum stress and bending moment; 2) whether codominant stems predispose shade trees to fail; and 3) whether stress at the point of tree failure is related to the modulus of rupture (MOR) of wood samples taken from the tree. Because the methodology replicated previous studies of forest conifers, a secondary objective was to compare results with those studies to determine whether mechanistic models of tree failure developed for forest trees could be applied to shade trees.

\section{METHODOLOGY}

Three common species were tested in this study, Norway (Acer platanoides L.), red (Acer rubrum L.), and sugar (Acer saccharum Marsh.) maples. Each has been planted extensively along streets and in residential yards in the Northeast and Mid-Atlantic states of the United States. In total, 30 trees were pulled to failure, but data from six trees were not collected properly as a result of a malfunction of the data logger. The trees were part of the landscaping of an institutional property in Belchertown, MA (USDA hardiness zone 5a). All trees had been planted as street trees, approximately $20 \mathrm{~m}(66 \mathrm{ft})$ apart from one another and 2 $\mathrm{m}(6.6 \mathrm{ft})$ from paved roads. This arrangement presumably restricted root growth under the road, but the remainder of the root system appeared to be unrestricted, although underground utilities were present in some cases. Because no trees failed by 
Table 1. Mean (standard deviation) morphometric data for trees of each species. ${ }^{2}$

\begin{tabular}{lllllll}
\hline Measure & $\mathrm{n}$ & $\mathrm{AP}$ & $\mathrm{n}$ & $\mathrm{AR}$ & $\mathrm{n}$ & $\mathrm{AS}$ \\
\hline Tree height (m) & 7 & $16.8(3.08)$ & 6 & $18.5(3.63)$ & 10 & $16.7(7.45)$ \\
dbh (m) & 7 & $0.45(0.11)$ & 7 & $0.71(0.15)$ & 10 & $0.71(0.13)$ \\
$\begin{array}{l}\text { Slenderness } \\
\quad \text { height/dbh) }\end{array}$ & 7 & $38.0(6.30)$ & 6 & $28.6(7.88)$ & 10 & $24.1(11.4)$ \\
Crown height (m) & 7 & $13.8(2.26)$ & 3 & $\mathrm{~nm}^{\mathrm{y}}$ & 6 & $17.2(2.42)$ \\
Crown width (m) & 5 & $12.6(4.39)$ & 2 & $\mathrm{~nm}^{\mathrm{y}}$ & 6 & $15.7(4.10)$ \\
\hline
\end{tabular}

${ }^{\mathrm{z}} \mathrm{AP}=$ Norway maple, $\mathrm{AR}=$ red maple, $\mathrm{AS}=$ sugar maple; $\mathrm{dbh}=$ diameter measured at breast height (1.4 $\mathrm{m}$ aboveground).

${ }^{\mathrm{y}} \mathrm{nm}$ indicates that there were too few samples to include in the analysis.

uprooting, compromised root systems were deemed to be irrelevant during testing. All trees were semimature to mature, but none was in declining health. Trees were chosen primarily according to practical considerations of the test procedure. Great care was needed when breaking large trees so that buildings, roads, aboveground utilities, and existing trees and shrubs on the property were not damaged. The availability of appropriate sites to conduct tests and the practical limitations of breaking large shade trees in situ naturally limited the scope of the study and the sample size. Before testing, tree height and diameter at breast height (dbh) were measured. Crown height and width were measured for 16 and 13 trees, respectively. Table 1 presents morphometric data for each species.

\section{Field Tests}

Tests were conducted in the summers of 2002, 2003, and 2005; site constraints limited the number of days available to conduct tests each year. Trees were pulled to failure using a cable winch skidder (John Deere model 440D [Moline, IL], hydraulic winch capacity $90 \mathrm{kN}$ ); the cable was run from the spool of the winch through a large block attached to the main trunk and back to an anchor point on the skidder (see Figure 1). The height of the block ranged from $37 \%$ to $81 \%$ (mean $=51 \%$ ) of tree height. The variation was the result of the necessity of securing the cable to a substantial portion of the trunk and of variation among trees in both tree height and crown structure. The block was attached at a height that incorporated a codominant stem when one existed in a tree. In such situations, the load was applied perpendicular to the attachment between the codominant stems. The distance from the skidder to the tree, the height of the winch spool and anchor point, and the horizontal distance between the spool and the anchor point were measured to determine the angle between the cable and the ground. The angle was necessary to resolve the applied load into components parallel and normal to the ground.

Tension in the cable was measured by placing a load cell (111 kN capacity, accurate to $111 \mathrm{~N}$; Futek Advanced Sensor Technology, Inc., Irvine, CA) between the anchor point on the skidder and the cable after it was passed around the sheave of the block. Measured tension was doubled to determine the actual load on the tree because the cable was run through the block. To measure fiber extension on the trunk, a linear variable displacement transducer (LVDT) (model TS50, accurate to $0.075 \mathrm{~mm}$ (0.003 in); Novotechnik U.S., Inc., Southborough, MA) was attached to the trunk at breast height on the side opposite the direction of the applied load (see Figure 2). Fiber extensions were converted to strains by dividing the fiber extension by the gauge length of the LVDT (50 mm [2 in]). Loads and fiber extensions were collected

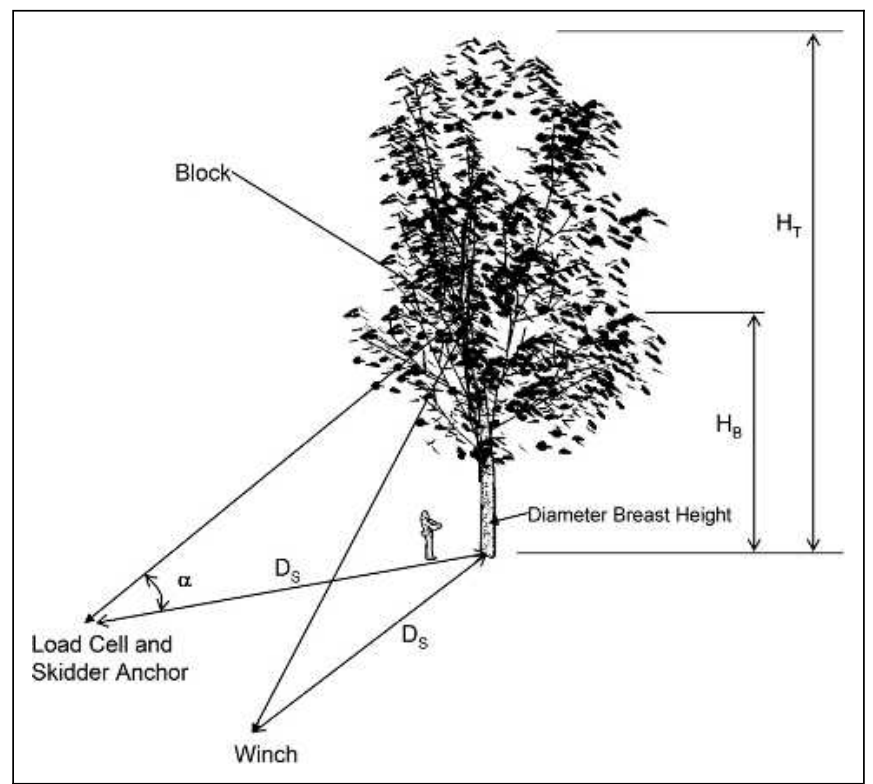

Figure 1. Diagram of tree-pulling setup. The dashed lines represent the cable with arrowheads indicating the tension. $D_{S}$ is the distance between the skidder and the tree, $H_{T}$ is the height of the tree, and $H_{B}$ is the height of the block. The angle $(\alpha)$ between the cable and the ground was calculated as $\tan ^{-1}\left(H_{B} / D_{S}\right)$. The distance between the winch and the skidder anchor was less than $2 \mathrm{~m}$.

at $2 \mathrm{~Hz}$ with a three-channel data logger (Mini-ModuLogger; Logic Beach, Inc., La Mesa, CA) that also recorded temperature and relative humidity. Trees were pulled until failure without stopping, which generally occurred within $15 \mathrm{sec}$ of applying the load (the maximum time to failure was $30 \mathrm{sec}$ ).

Tests during the summers of 2003 and 2005 were videotaped to quantify the amount of deflection of the crown during tests. Video images were scaled and the distance traveled by the block attached to the trunk was measured on the video image. The horizontal deflection of the crown adds a bending moment as a result of the offset mass of the crown. Crown mass was not measured, which means that the reported stress values underestimate the actual breaking stress. Because the horizontal deflection of the block did not exceed $2 \mathrm{~m}(6.6 \mathrm{ft})$ for any tree, the bending moment resulting from the offset mass of the crown was likely negligible relative to the applied load.

After failure, a clean cross-section adjacent to the point of failure was cut with a chainsaw and the dimensions of the crosssection were measured parallel and normal to the direction of the applied load. The distance between the block and the point of failure was also measured. Decay and other defects on the trunk and cross-section were also noted and quantified with a digital image. Failure was categorized by its location either along the trunk (stem failures) or at the attachment between codominant stems (codominant failures).

\section{Stress Analysis}

Compressive stress $(\sigma)$ at the point of failure was calculated by adding the bending stress (the first fraction in Equation 1) and axial stress (the second fraction in Equation 1) resulting from the applied load:

$$
\sigma=32 \mathrm{P} \cos \alpha 1 /\left(\pi \mathrm{ab}^{2}\right)+4 \mathrm{P} \sin \alpha /(\pi \mathrm{ab})
$$




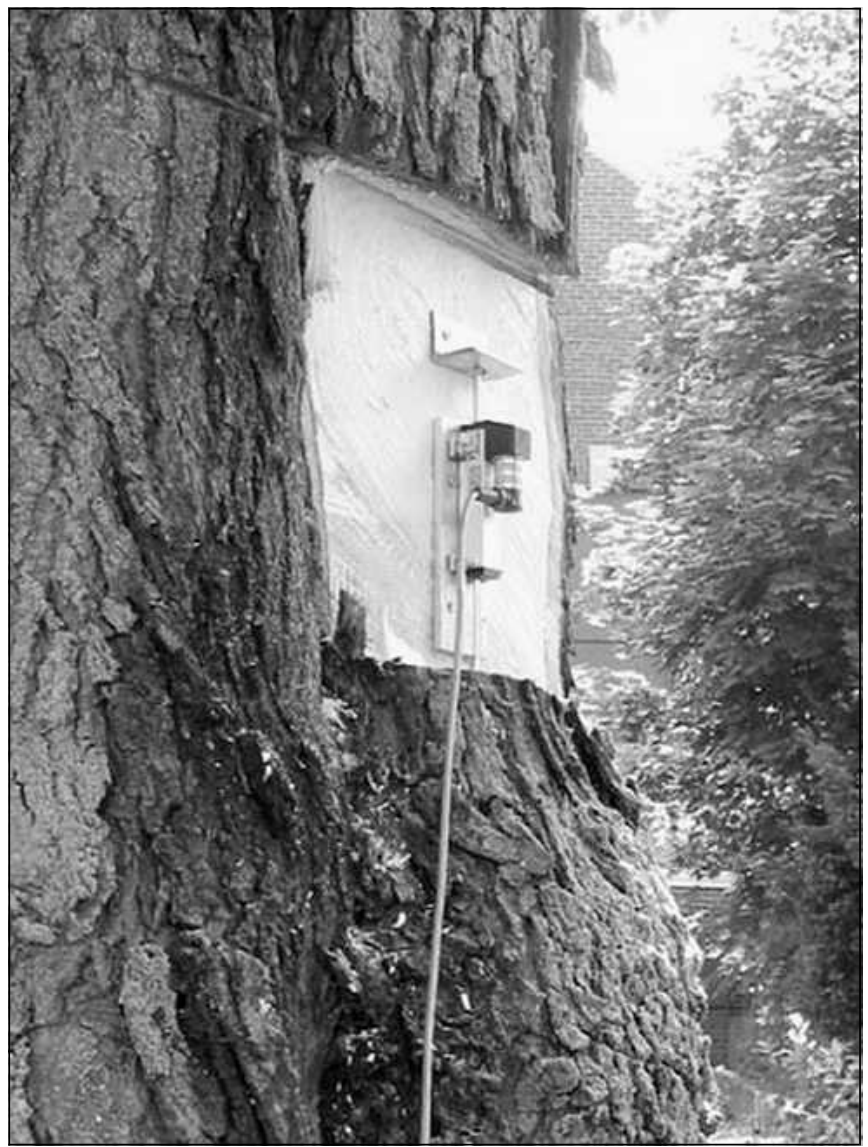

Figure 2. Linear variable displacement transducer setup used to measure fiber strain.

where $\mathrm{P}$ is twice the tension in the cable, $\alpha$ is the angle between the cable and the ground, 1 is the distance between the block and the point of failure, and $\mathrm{a}$ and $\mathrm{b}$ are the dimensions of the stem cross-section normal and parallel to, respectively, the applied load. Stress was also calculated on the trunk at breast height (1.4 $\mathrm{m}[4.6 \mathrm{ft}]$ aboveground) using Equation 1 (except that 1 repre-

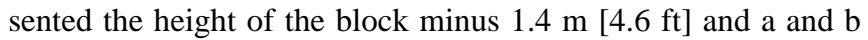
represented the corresponding cross-sectional dimensions at breast height). A substantial portion of the trunk cross-section was decayed on one red maple. For that tree, the decayed portion was omitted from the stress calculation by calculating both the area and second moment of area of the cross-section using a photograph of the cross-section and the parallel axis theorem (Lardner and Archer 1994). This procedure was described in detail by Kane and Ryan (2004).

\section{Laboratory Tests}

A bolt of wood was removed from the stem, adjacent to the point of failure, and four wood samples (one from each compass direction, assuming North was the direction in which the load was applied) were machined from each bolt. Samples $(2.54 \mathrm{~cm}[1.02$ in] $\times 2.54 \mathrm{~cm}$ [1.02 in] $\times 40.64 \mathrm{~cm}$ [16.26 in]) were tested in a three-point bending test as described in the American Society of Testing Materials D-143 Standard (ASTM 2000) to determine MOR and Young's modulus (MOE) of the samples. Samples from trees pulled in 2005 were loaded at twice the speed speci- fied by the D-143 Standard, but this was assumed not to influence results because a 10\% increase in MOR requires an increase of 10 times the loading rate (Green et al. 1999). The average MOR and MOE were calculated from the four samples of each tree; in cases in which a specimen failed at a knot or other defect, that value was excluded from the average.

MOE of the trunk at breast height was determined by fitting a straight line to the plot of stress versus strain at breast height for each tree. The slope of the line is MOE. Strain at breast height was linear for every tree, indicating that fibers in the trunk at breast height did not go beyond the elastic range.

To compare stresses measured during tree-pulling tests with stresses endured during wind loading, trunk strains $(\varepsilon)$ on a sugar maple $(85 \mathrm{~cm}$ [33 in] dbh) and a sycamore maple (Acer pseduoplatanus L.; (70 cm [27 in] dbh) were each measured for $2 \mathrm{hr}$ on a windy day using the method described by James et al. (2006). Both trees were dormant and leafless during data collection. Previously, trunk strain had been measured while each tree was loaded with a winch at the height of the approximate center of pressure. The load was converted to trunk stress using Equation 1 and MOE of the trunk was calculated using Hooke's Law:

$$
\mathrm{MOE}=\sigma / \varepsilon \text { or } \sigma=\mathrm{MOE}^{*} \varepsilon
$$

Hooke's Law only applies when the stress/strain relationship is linear, and because the relationship was linear for all trees pulled to failure, it was safe to assume that the relationship was linear for all measured wind speeds $(11.9 \mathrm{~m} / \mathrm{s}$ [27 mph] or less). The maximum strain measured on the windy day was converted into a stress using Equation 2 and this value was compared with stresses at the point of failure and at breast height for trees pulled to failure.

As a result of the small sample size and similarity among species with respect to tree morphometric data (Table 1), data from all species were pooled for analysis. Data were tested for normality using the Kolmogorov-Smirnov test and were found to be normally distributed. Within each failure type (stem or codominants), a paired t-test was used to compare 1) stress at the point of failure and at breast height; 2) bending moment at the point of failure and at breast height; and 3) stress at the point of failure with MOR of wood samples. MOE of whole trees was not compared with MOE of wood samples because samples were not taken from the height at which the strain gauge was placed on the trunk. A t-test was used to determine whether stress and bending moment at the point of failure, maximum tension in the cable, and MOR of wood samples differed between stem failures and codominant failures. The relationship between tree morphometric data and both trunk stress and bending moment at the point of failure was investigated for all trees and within each failure type using linear regression analysis. All analyses were conducted in SAS (version 9.1; SAS Institute, Cary, NC).

\section{RESULTS}

There were 13 codominant failures and 11 stem failures. No trees with codominant stems below the height of attachment of the block exhibited stem failure, and all of the stem failures occurred at a lateral branch(es) along the main trunk. No trees uprooted during the tests; one additional tree was intentionally uprooted, however, by applying the load sufficiently close to the ground for the sake of comparison with stem and codominant failures.

There were many similarities between stem failures and codominant failures (Table 2). Trees from both categories were 
Table 2. Means (standard deviation) for tree morphometric data, stress $(\sigma)$, bending moment $(M)$, cable tension $(P)$, and modulus of rupture of wood samples (MOR) for stem and codominant failures.

\begin{tabular}{|c|c|c|c|c|c|}
\hline \multirow[b]{2}{*}{ Variable } & \multicolumn{2}{|r|}{ Stem failures } & \multicolumn{2}{|c|}{ Codominant failures } & \multirow{2}{*}{$\frac{\text { Difference }^{z}}{P}$} \\
\hline & $\mathrm{n}$ & Mean (SD) & $\mathrm{n}$ & Mean (SD) & \\
\hline $\mathrm{dbh}(\mathrm{m})$ & 11 & $0.57(0.16)$ & 13 & $0.69(0.17)$ & 0.1072 \\
\hline Tree height (m) & 11 & $18.0(5.72)$ & 12 & $16.5(4.98)$ & 0.5303 \\
\hline $\begin{array}{l}\text { Slenderness } \\
\text { (height/dbh) }\end{array}$ & 11 & $31.8(7.62)$ & 12 & $27.4(12.4)$ & 0.3227 \\
\hline $\begin{array}{l}\text { Crown height } \\
\text { (m) }\end{array}$ & 9 & $14.6(3.00)$ & 7 & $16.1(2.03)$ & 0.2698 \\
\hline $\begin{array}{l}\text { Crown width } \\
\text { (m) }\end{array}$ & 7 & $16.2(3.87)$ & 6 & $12.9(4.66)$ & 0.1955 \\
\hline $\begin{array}{l}\text { Block height/tree } \\
\text { height }\end{array}$ & 11 & $0.53(0.11)$ & 12 & $0.56(0.12)$ & 0.5255 \\
\hline $\begin{array}{l}\text { Stem volume } \\
\left(\mathrm{m}^{3}\right)\end{array}$ & 11 & $6.90(4.79)$ & 12 & $7.15(2.88)$ & 0.8843 \\
\hline $\mathrm{P}(\mathrm{kN})$ & 11 & $18.0(11.6)$ & 13 & $13.9(7.28)$ & 0.2971 \\
\hline $\mathrm{M}_{\mathrm{FP}}^{\mathrm{y}}(\mathrm{kN} * \mathrm{~m})$ & 11 & $110(103)$ & 13 & $137(87.1)$ & 0.4989 \\
\hline $\mathrm{M}_{\mathrm{BH}}^{\mathrm{y}}(\mathrm{kN} * \mathrm{~m})$ & 11 & $278(209)$ & 13 & $216(104)$ & 0.3847 \\
\hline$\sigma_{\mathrm{FP}}(\mathrm{kPa})$ & 11 & $51,193(20,521)$ & 13 & $25,230(15,442)$ & 0.0029 \\
\hline$\sigma_{\mathrm{BH}}(\mathrm{kPa})$ & 11 & $12,117(5,816)$ & 13 & $7,138(3,897)$ & 0.0280 \\
\hline MOR (kPa) & 10 & $62,596(11,287)$ & 11 & $71,214(22,764)$ & 0.3004 \\
\hline $\begin{array}{l}\text { Distance to } \\
\text { failure (m) }\end{array}$ & 11 & $3.12(1.55)$ & 13 & $5.55(2.15)$ & 0.0041 \\
\hline $\begin{array}{l}\text { Diameter at } \\
\text { failure }(\mathrm{m})\end{array}$ & 11 & $0.30(0.15)$ & 13 & $0.45(0.18)$ & 0.0433 \\
\hline $\begin{array}{l}\text { Height of } \\
\quad \text { failure (m) }\end{array}$ & 11 & $6.00(2.15)$ & 12 & $3.06(3.09)$ & 0.0044 \\
\hline $\begin{array}{l}\text { Diameter at } \\
\text { failure/dbh }\end{array}$ & 11 & $0.53(0.20)$ & 13 & $0.67(0.27)$ & 0.1406 \\
\hline
\end{tabular}

similar in size: there were no significant differences in tree height, slenderness, crown height and width, stem volume, or cable tension. There was weak evidence that dbh of stem failures was less than codominant failures. MOR of samples was similar for both types of failure.

There were a few statistical differences between stem and codominant failures, however, and these were important (Table 2). They did not appear to be related to the experimental procedure because the ratio of block height to tree height was similar for both types of failure. Although stem and codominant failures experienced similar bending moments at the point of failure, stem failures required more than twice the stress of codominant failures. The distance to failure from the block was $2.4 \mathrm{~m} \mathrm{(7.9} \mathrm{ft)}$ longer for codominant failures, which made diameter at the point of failure $0.14 \mathrm{~m}(0.5 \mathrm{ft})$ greater for codominant failures. Stem failures occurred twice as high in the crown as codominant failures, and all but one stem failure occurred above the base of the crown. In contrast, two-thirds of codominant failures occurred at the base of the crown.

For both failure types, stress at the point of failure was greater than stress at breast height, but the mean difference was more than twice as great for stem failures as codominant failures (Table 3). Stress at the point of failure was less than MOR of wood samples for codominant failures and there was some evidence that this was also true of stem failures, but the difference was not nearly as large. Bending moment at the point of failure was consistently less than at breast height regardless of the location of failure.

Only diameter at breast height and diameter at breast height cubed produced statistically significant predictions of stress at the point of failure for all trees, but neither variable explained more than $17 \%$ of the variance of stress at the point of failure (Table 4). For stem failures, there was some evidence that stress at the point of failure was inversely proportional to crown width. Although there were no statistically significant predictors of stress at the point of failure when trees were separated by the type of failure, correlation coefficients were generally greater for stem failures than codominant failures (Table 4).

When grouping all trees, bending moment at the point of failure was directly and linearly proportional to $\mathrm{dbh}$, dbh cubed, and stem volume (Table 5). These relationships were the same when considering only stem failures, but not for codominant failures, which were independent of stem properties. Correlation coefficients were greater for regressions of bending moment at the point of failure than stress at the point of failure for all trees as well as when trees were separated by type of failure.

The single tree that was pulled to ensure root failure required a bending moment at the root flare of $801 \mathrm{kN} * \mathrm{~m}$, somewhat greater than the largest bending moment of any other tree, which was $741 \mathrm{kN*m}$. Both of these trees were sugar maples, approximately $85 \mathrm{~cm}$ (33 in) dbh. Stress at breast height was $12,690 \mathrm{kPa}$ for the uprooted tree and $15,400 \mathrm{kPa}$ for the other sugar maple; stress at the point of failure was $24,380 \mathrm{kPa}$ for the other sugar maple.

\section{DISCUSSION}

\section{Failure Type}

The lack of root failures in the current study does not agree with observations of failed trees after storms (Gibbs and Greig 1990; Duryea et al. 1996; Jim and Liu 1997), but root failures are likely the result of the presence of defects such as decay that compromised root systems before wind loading (Gibbs and Greig 1990; Jim and Liu 1997). For forest trees, stem failure was more likely

Table 3. Mean difference (standard deviation) and $P$ value between paired comparisons for each failure type.

\begin{tabular}{|c|c|c|c|c|c|c|}
\hline \multirow[b]{2}{*}{ Paired comparison } & \multicolumn{3}{|c|}{ Stem failures } & \multicolumn{3}{|c|}{ Codominant failures } \\
\hline & $\mathrm{n}$ & Mean (SD) & $P$ & $\mathrm{n}$ & Mean (SD) & $P$ \\
\hline Stress at failure point - stress at breast height* $(\mathrm{kPa})$ & 11 & $39,076(20,812)$ & 0.0001 & 13 & $18,092(14,125)$ & 0.0006 \\
\hline Stress at failure point $-\mathrm{MOR}^{\mathrm{y}}(\mathrm{kPa})$ & 10 & $-12,674(19,862)$ & 0.0744 & 11 & $-42,701(28,839)$ & 0.0006 \\
\hline Bending moment at failure point - bending moment at breast height $\left(\mathrm{kN}^{*} \mathrm{~m}\right)$ & 11 & $-169(119)$ & 0.0008 & 13 & $-78.4(63.7)$ & 0.0008 \\
\hline
\end{tabular}

${ }^{\mathrm{z}}$ Breast height is $1.4 \mathrm{~m}(4.6 \mathrm{ft})$ aboveground.

${ }^{\mathrm{y}} \mathrm{MOR}=$ modulus of rupture.

$\mathrm{SD}=$ standard deviation. 
Table 4. Predictions of stress at the point of failure from tree morphometric data and wood strength (MOR) for all trees, stem failures, and codominant failures.

\begin{tabular}{|c|c|c|c|c|c|c|c|c|c|c|c|c|c|}
\hline \multirow{2}{*}{ Variable ${ }^{\mathrm{z}}$} & & \multicolumn{4}{|c|}{ All trees } & \multicolumn{4}{|c|}{ Stem failures } & \multicolumn{4}{|c|}{ Codominant failures } \\
\hline & & $\mathrm{n}$ & Estimate (SE) & $P$ & $\mathrm{RMSE} / \mathrm{R}^{2}$ & $\mathrm{n}$ & Estimate (SE) & $P$ & $\mathrm{RMSE} / \mathrm{R}^{2}$ & $\mathrm{n}$ & Estimate (SE) & $P$ & $\mathrm{RMSE} / \mathrm{R}^{2}$ \\
\hline & $\mathrm{B}^{\mathrm{y}}$ & 21 & $42,214(17,428)$ & 0.0256 & $21,270 / 0.00$ & 10 & $5,444(38,969)$ & 0.8923 & $20,780 / 0.14$ & 10 & $31,337(15,404)$ & 0.0724 & $15,536 / 0.00$ \\
\hline $\operatorname{MOR}(\mathrm{kPa})$ & $\beta^{y}$ & & $-0.052(0.250)$ & 0.8369 & & & $0.71(0.61)$ & 0.2803 & & & $-0.04(0.21)$ & 0.8517 & \\
\hline \multirow{3}{*}{$\begin{array}{l}\text { Tree height } \\
\text { (m) }\end{array}$} & B & 24 & $42,050(16,419)$ & 0.0182 & $23,034 / 0.00$ & 11 & $77,714(21,133)$ & 0.0051 & $19,827 / 0.16$ & 12 & $22,006(16,723)$ & 0.2176 & $16,695 / 0.00$ \\
\hline & $\beta$ & & $-288(913)$ & 0.7553 & & & $-1,473(1126)$ & 0.2232 & & & $132(975)$ & 0.8954 & \\
\hline & B & 24 & $70,256(16,289)$ & 0.0003 & $20,581 / 0.17$ & 11 & $86,741(22,942)$ & 0.0043 & $19,084 / 0.22$ & 13 & $31,329(19,047)$ & 0.1282 & $16,347 / 0.01$ \\
\hline \multirow[t]{2}{*}{$\mathrm{dbh}(\mathrm{m})$} & $\beta$ & & $-52,155(24,778)$ & 0.0469 & & & $-62,068(38,776)$ & 0.1439 & & & $-8,879(26,930)$ & 0.7478 & \\
\hline & B & 23 & $27,513(14,226)$ & 0.0667 & $22,813 / 0.02$ & 11 & $52,749(29,128)$ & 0.1036 & $21,627 / 0.00$ & 12 & $21,420(11,718)$ & 0.0975 & $16,655 / 0.01$ \\
\hline Slenderness & $\beta$ & & $324(454)$ & 0.4828 & & & $-48.8(890)$ & 0.9575 & & & $100(391)$ & 0.8024 & \\
\hline \multirow{2}{*}{$\begin{array}{l}\text { Crown height } \\
\text { (m) }\end{array}$} & B & 16 & $75,623(34,499)$ & 0.0458 & $22,849 / 0.08$ & 9 & $55,667(37,272)$ & 0.1789 & $20,957 / 0.00$ & 7 & $94,889(68,880)$ & 0.2268 & $19,376 / 0.18$ \\
\hline & $\beta$ & & $-2,435(2229)$ & 0.2932 & & & $-408(2477)$ & 0.8737 & & & $-4,385(4,243)$ & 0.3487 & \\
\hline \multirow{2}{*}{$\begin{array}{l}\text { Crown width } \\
\text { (m) }\end{array}$} & B & 16 & $75,623(34,499)$ & 0.0458 & $22,849 / 0.08$ & 7 & $90,734(23,481)$ & 0.0118 & $13,441 / 0.46$ & 7 & $45,985(29,390)$ & 0.1927 & $21,372 / 0.11$ \\
\hline & $\beta$ & & $-2,435(2229)$ & 0.2932 & & & $-2,967(1432)$ & 0.0931 & & & $-1,504(2159)$ & 0.5245 & \\
\hline \multirow{3}{*}{$\begin{array}{l}\text { Stem volume } \\
\left(\mathrm{m}^{3}\right)\end{array}$} & B & 23 & $49,156(9,816)$ & 0.0001 & $22,092 / 0.08$ & 11 & $64,497(10,547)$ & 0.0002 & $19,314 / 0.20$ & 12 & $29,673(13,276)$ & 0.0494 & $16,547 / 0.02$ \\
\hline & $\beta$ & & $-1,716(1233)$ & 0.1786 & & & $-1,927(1274)$ & 0.1646 & & & $-770(1733)$ & 0.6661 & \\
\hline & B & 24 & $48,830(7,232)$ & 0.0001 & $20,799 / 0.15$ & 11 & $64,419(9,838)$ & 0.0001 & $18,949 / 0.23$ & 13 & $27,241(8,411)$ & 0.0079 & $16,368 / 0.01$ \\
\hline$(\mathrm{dbh})^{3}\left(\mathrm{~m}^{3}\right)$ & $\beta$ & & $-37,601(18,834)$ & 0.0584 & & & $-58,430(35,380)$ & 0.1330 & & & $-5,229(18,409)$ & 0.7817 & \\
\hline
\end{tabular}

${ }^{\mathrm{z}} \mathrm{dbh}=$ diameter at breast height; slenderness $=$ tree height $/ \mathrm{dbh}$; stem volume $=$ tree height $*(\mathrm{dbh})^{2}$.

${ }^{\mathrm{y}} \mathrm{B}, \beta=$ intercept and slope, respectively, of best fit line for the plot of stress at the point of failure and the variable listed in the first column.

$\mathrm{SE}=$ standard error; RMSE $=$ root mean square error.

when roots were not decayed or restricted by soil conditions (Fraser 1962; Somerville 1979; Moore 2000; Peltola et al. 2000).

Codominant stems were clearly a significant structural defect for large maples, which agreed with prior observations of failures of multitrunk trees and branches (Gibbs and Greig 1990). More than half of the maples considered hazardous in Helsinki, Finland, were deemed hazardous by virtue of poor branch attachments, including codominant stems (Terho and Hallaksela 2005). A frequency analysis of the International Tree Failure Database (ITFD; data downloaded in March 2007 from http:// ftcweb.fs.fed.us/natfdb/) shows that $36 \%$ of 1627 trunk failures occurred when codominant stems were involved.
Although it was not part of this investigation to determine the cause of weakness of codominant stems, two explanations offer some insight. One codominant failure was observed not to have bark occluded among the stems, unlike every other codominant failure. The failure stress for this tree was $74 \%$ greater than the next largest value for a codominant failure. Although our study supports the idea that the presence of occluded bark reduces tree strength, the influence of bark occlusions with respect to failure stress is not entirely clear in the literature. Smiley (2003) found that bark occlusions reduced the strength of the attachment among codominant branches of small red maples, but others suggested that the most reliable predictor of branch attachment

Table 5. Predictions of bending moment at the point of failure from tree morphometric data and wood strength (MOR) for all trees, stem failures, and codominant failures.

\begin{tabular}{|c|c|c|c|c|c|c|c|c|c|c|c|c|c|}
\hline \multirow[b]{2}{*}{ Variable $^{z}$} & & \multicolumn{4}{|c|}{ All failures } & \multicolumn{4}{|c|}{ Stem failures } & \multicolumn{4}{|c|}{ Codominant failures } \\
\hline & & $\mathrm{n}$ & Estimate (SE) & $P$ & RMSE/R ${ }^{2}$ & $\mathrm{n}$ & Estimate (SE) & $P$ & $\mathrm{RMSE} / \mathrm{R}^{2}$ & $\mathrm{n}$ & Estimate (SE) & $P$ & $\mathrm{RMSE} / \mathrm{R}^{2}$ \\
\hline & $\mathrm{B}^{\mathrm{y}}$ & 21 & $169(77.8)$ & 0.0430 & $95.0 / 0.01$ & 10 & $162(207)$ & 0.4567 & $110 / 0.01$ & 11 & $210(83.5)$ & 0.0328 & $84.2 / 0.05$ \\
\hline $\operatorname{MOR}(\mathrm{kPa})$ & $\beta^{\mathrm{y}}$ & & $-0.0004(0.0011)$ & 0.7013 & & & $-0.0007(0.0033)$ & 0.8386 & & & $-0.0007(0.0011)$ & 0.5300 & \\
\hline \multirow{3}{*}{$\begin{array}{l}\text { Tree height } \\
\text { (m) }\end{array}$} & $\mathrm{B}$ & 23 & $75.6(70.2)$ & 0.2936 & $97.2 / 0.02$ & 11 & $14.5(111)$ & 0.8989 & $104 / 0.08$ & 12 & $121(96.7)$ & 0.2404 & $96.5 / 0.00$ \\
\hline & $\beta$ & & $2.65(3.91)$ & 0.5056 & & & $5.29(5.93)$ & 0.3954 & & & $0.6607(5.64)$ & 0.9091 & \\
\hline & $\mathrm{B}$ & 24 & $-53.2(66.6)$ & 0.4334 & $84.2 / 0.26$ & 11 & $-156(93.7)$ & 0.1309 & $78.0 / 0.49$ & 13 & 21.9 (104) & 0.8373 & $89.5 / 0.11$ \\
\hline $\mathrm{dbh}(\mathrm{m})$ & $\beta$ & & $280(101)$ & 0.0113 & & & $464(158)$ & 0.0169 & & & $168(148)$ & 0.2789 & \\
\hline \multirow{2}{*}{$\begin{array}{l}\text { Crown height } \\
\text { (m) }\end{array}$} & $\mathrm{B}$ & 16 & $-22.6(141)$ & 0.8751 & $90.5 / 0.06$ & 9 & $-26.2(204)$ & 0.9012 & $115 / 0.07$ & 7 & $-73.83(230)$ & 0.7616 & $64.8 / 0.11$ \\
\hline & $\beta$ & & $8.82(9.07)$ & 0.3468 & & & $9.69(13.5)$ & 0.4973 & & & $11.3(14.2)$ & 0.4634 & \\
\hline \multirow{3}{*}{$\begin{array}{l}\text { Crown width } \\
\quad(\mathrm{m})\end{array}$} & $\mathrm{B}$ & 13 & $42.0(90.8)$ & 0.6527 & 87.8/0.09 & 7 & $-79.4(190)$ & 0.6934 & $109 / 0.22$ & 6 & $134(85.4)$ & 0.1926 & $62.1 / 0.01$ \\
\hline & $\beta$ & & $6.27(5.99)$ & 0.3176 & & & $13.9(11.6)$ & 0.2831 & & & $-0.8982(6.27)$ & 0.8931 & \\
\hline & B & 23 & $172(60.1)$ & 0.0092 & $96.4 / 0.04$ & 11 & $263(137)$ & 0.087 & $102 / 0.13$ & 12 & $146(67.8)$ & 0.0563 & $96.3 / 0.01$ \\
\hline Slenderness & $\beta$ & & $-1.74(1.92)$ & 0.3753 & & & $-4.81(4.18)$ & 0.2804 & & & $-0.5386(2.26)$ & 0.8165 & \\
\hline \multirow{3}{*}{$\begin{array}{l}\text { Stem volume } \\
\left(\mathrm{m}^{3}\right)\end{array}$} & $\mathrm{B}$ & 23 & $26.5(36.9)$ & 0.4794 & $83.0 / 0.29$ & 11 & $16.6(46.4)$ & 0.7288 & $84.9 / 0.39$ & 12 & $38.3(70.8)$ & 0.6004 & $88.2 / 0.17$ \\
\hline & $\beta$ & & $13.5(4.63)$ & 0.0085 & & & $13.5(5.60)$ & 0.0392 & & & $13.0(9.24)$ & 0.1881 & \\
\hline & $\mathrm{B}$ & 24 & $56.9(28.9)$ & 0.0617 & $83.1 / 0.28$ & 11 & $3.42(36.1)$ & 0.9266 & $69.5 / 0.59$ & 13 & $86.0(45.0)$ & 0.0827 & $87.6 / 0.14$ \\
\hline $\mathrm{dbh}^{3}\left(\mathrm{~m}^{3}\right)$ & $\beta$ & & $217(75.1)$ & 0.0084 & & & $470(130)$ & 0.0056 & & & $134(98.6)$ & 0.2026 & \\
\hline
\end{tabular}

${ }^{\mathrm{z}} \mathrm{dbh}=$ diameter at breast height; slenderness $=$ tree height $/ \mathrm{dbh}$; stem volume $=$ tree height $*(\mathrm{dbh})^{2}$.

${ }^{\mathrm{y}} \mathrm{B}, \beta=$ intercept and slope, respectively, of best fit line for the plot of bending moment at the point of failure and the variable listed in the first column. $\mathrm{SE}=$ standard error; RMSE $=$ root mean square error. 
strength was the ratio of branch diameter to trunk diameter at the point of attachment, regardless of whether bark occlusions were present (Miller 1959; Gilman 2003). Bark occlusions were present for $21 \%$ of 1627 trunk failures recorded in the ITFD (data downloaded in March 2007 from http://ftcweb.fs.fed.us/natfdb/).

A second explanation considered the orientation of wood fibers and the corresponding initial mode of failure of codominant stems. Video footage revealed that failure initiated in a complex combined stress state at the attachment: through combined shear and tension. Both shear and tension perpendicular to the grain are significantly weaker failure modes of wood than tension parallel to the grain (Green et al. 1999) and therefore more likely the governing factors. A crack was then observed to have formed pulling the fibers apart parallel to the long axis of the trunk and effectively splitting it in two. Supporting this speculation, the mean stress at the point of failure of codominant failures was approximately one-half of stress for stem failures-the value expected if the cross-section that resisted bending were one-half of the measured cross-section. In some cases, there was obvious splintering of fibers (typical of tensile parallel-to-grain failure) in the side of the trunk expected to be under compressive stress if the entire trunk were stressed, i.e., proximal to the applied load. Furthermore, for six of the nine codominant failures that occurred within $2.5 \mathrm{~m}(8.3 \mathrm{ft})$ of the ground, no trunk strains were recorded, indicating that that side of the trunk was separate and did not contribute to tree strength. The effect of shear and tension perpendicular to the grain should be considered more carefully in future investigations of codominant stems and branch attachments.

Bending moment was found to be statistically similar for stem and codominant failures, but distance to failure was significantly larger for codominant trees. This implies that failure load was lower, but that was not the case, presumably as a result of large variability among trees within each failure type. Such variability can be attributed to size differences among trees. It is also speculated that the difference in calculated stress at the point of failure between stem and codominant failures was partially the result of differences in cross-sectional dimension at the point of failure and the weaker failure mode of codominants. Differences in diameter at failure were the result of the greater height of failure of stem failures.

The apparently contradictory findings that bending moments were similar between failure types whereas stem failures required twice the stress of codominant failures can be explained by the weaker failure mode of the codominants. Furthermore, greater diameter at the point of failure for codominant failures resulted in lower stresses. Because stress is inversely proportional to the cube of diameter, a small increase in diameter can cause a large decrease in stress.

Variations in stem shape help explain why the correlation coefficients for predictions of bending moment were greater than for stress for both failure types. Stem cross-sections were considered ellipses, but none was a perfect ellipse, which introduced some error into the calculation of stress. For codominant failures, the weak correlation between $\mathrm{dbh}$ and bending moment was presumably the result of the influence of tension perpendicular to grain failure. Furthermore, the lack of correlation between dbh and stress was likely the result of orientation of stress (perpendicular to grain) and the assumed shape and orthotropy of the stem cross-section at failure. Future studies could focus on refinement of prediction models for codominant tree failures.
Although codominant stems constituted a significant structural defect, none appeared to be in imminent danger of failing. As a point of comparison, for a wind speed of $11.9 \mathrm{~m} / \mathrm{s}(27 \mathrm{mph})$, the maximum stress measured on the sycamore maple was 510 $\mathrm{kPa}$. On the sugar maple, the maximum stress was $2190 \mathrm{kPa}$ when the maximum wind speed was $11.4 \mathrm{~m} / \mathrm{s}$ ( $25 \mathrm{mph})$. Both of these values were much less than the average stress at breast height for all stem and codominant failures (Table 2), but the lack of foliage certainly reduced stress on the trees measured in the wind. It is also important to consider that stress determined by a static pull test will overestimate breaking stress endured during dynamic loading that occurs during windstorms (Oliver and Mayhead 1974).

Although stem failures occurred at greater stress than codominant failures, it was likely that lateral branches still constituted a trunk defect. The orientation of branch and trunk fibers at the point of branch attachment presumably causes the point of weakness. Moore (2000) also observed that stem failures often occurred at lateral branches. Fredericksen et al. (1993) noted that stem failures of winched loblolly pines (Pinus taeda L.) generally occurred closer to ground than trees damaged during a storm, an artifact of the height of the applied load. This was not the case for maples, presumably because defects (i.e., lateral branches and codominant stems) were incorporated below the height of applied load. The mean height of failure for all maples was $26 \%$ of tree height, which is almost identical to the mean of 25\% from the ITFD (data downloaded in March 2007 from http://ftcweb.fs.fed.us/natfdb/).

The lack of stem failures close to the ground and the substantially smaller stress at breast height compared with the point of failure have important implications for practitioners, who often assess tree risk by investigating trunk decay within a few meters of the ground. For stress at breast height to have been equal to stress at the point of failure, maples would have to have been $82 \%$ hollow at breast height. This value is larger than the common guideline that a trunk that is $70 \%$ hollow constitutes a substantial defect (Kane et al. 2001). Assessing defects higher in the crown may be more useful in predicting failure.

\section{Bending Moment and Stress at the Point of Failure}

Elementary mechanical principles explain why stress and bending moment at the point of failure were greater than and less than, respectively, stress and bending moment at breast height. Bending moment is the product of the applied load and the lever arm. At the point of failure, the lever arm was the distance between the block and the point of failure; at breast height, it was the height of the block less $1.4 \mathrm{~m}(4.6 \mathrm{ft})$. For the maximum applied load, the greater lever arm at breast height caused the bending moment to be greater. Because stress was inversely proportional to the cube of diameter, and diameter at breast height was larger than at the point of failure, stress was expected to be less. This was true although the bending moment was greater at breast height because the inverse relationship between stress and diameter is nonlinear.

Stress at the point of failure for stem and codominant failures, respectively, was $79 \%$ and $45 \%$ of the MOR of wood samples. For stem failures, Fons and Pong (1957) reported that failure stress was $70 \%$ of published MOR values for ponderosa pine (Pinus ponderosa P\&C Lawson), and Peltola et al. (1999) suggested that failure stress was $85 \%$ of published MOR values for 
Norway spruce [Picea abies (L.) Karst.], Scots pine (Pinus sylvestris L.), and birch (Betula spp.). Part of the disparity between tree stress and wood samples can be explained by the fact that stress at the point of failure was based on outside bark diameter. Because bark has a lower MOR than wood, adding bark to the diameter of wood that resists bending underestimates the actual stress. MOR values for wood samples of red and sugar maples in this study were similar to those published in the Wood Handbook (Green et al. 1999), whereas MOR values for Norway maples were less than those from trees sampled in Germany (Hannover and Schaper 2003). It appears that shade tree risk assessment models that use a static pulling test and Hooke's Law to quantify stem defects (e.g., Brudi and van Wassenaer 2001) may overestimate bending strength and therefore underestimate the risk of failure because such models use wood properties taken from samples, not entire trees.

\section{Prediction of Bending Moment and Stress at the Point of Failure}

The inverse relationship between stress and diameter cubed explains why diameter at breast height and diameter at breast height cubed were somewhat reliable predictors of stress at the point of failure. The relationships between bending moment at the point of failure and measures of tree size were the result of the fact that bending moment is directly proportional to the fourth power of diameter (Lardner and Archer 1994). The fact that bending moment at the point of failure for codominant failures was not reliably predicted by measures of tree size for codominant failures supports the notion that codominant stems constitute structural defects, although the small sample size may have undermined predictions. This notion is further supported by the fact that stress at the point of failure for codominants was only $45 \%$ of the MOR of wood samples. Measures of tree size such as dbh, dbh cubed, and stem volume were excellent predictors of the maximum bending moment for stem failures of forest conifers (Fredericksen et al. 1993; Papesch et al. 1997; Moore 2000; Peltola et al. 2000) with most $\mathrm{R}^{2}$ values greater than 0.90. Coefficients of determination from those studies were much greater than was found for maples in the current study, indicating the importance of defects in causing failure.

Slenderness was inversely proportional to the maximum bending moment and stress of forest trees (Petty and Swain 1985; Milne and Blackburn 1989; Fredericksen et al. 1993; Peltola et al. 2000), but was not a reliable predictor of bending moment or stress at the point of failure for maples, regardless of the type of failure. This was likely the result of forest trees from previous studies being noticeably more slender than maples. The least slender trees were tested in New Zealand (height/dbh $\cong 50$ ) (Papesch et al. 1997; Moore 2000), but values are commonly twice as large (Blackburn et al. 1988; Peltola et al. 2000). Typical values of slenderness in windthrow models range from 80 to 120 (Peltola et al. 1999; Ancelin et al. 2004).

\section{Comparison to Forest Conifers}

Most previous studies have reported that root failures were more common than stem failures (Smith et al. 1987; Papesch et al. 1997; Moore 2000; Peltola et al. 2000; Achim et al. 2004), which is attributable in part to the height at which the load was applied. In most cases, it was between one-third and one-half of tree height, less than the height at which a uniform distribution of stress along the trunk would occur (i.e., $80 \%$ of tree height)
(Wood 1995). When stem failures occurred, however, the vast majority occurred below $10 \%$ of tree height (Moore 2000) or closer to the ground (Fredericksen et al. 1993; Peltola et al. 2000). In contrast, although the load was applied, on average, at approximately the same height as previous studies, only two maples failed below $11 \%$ of tree height; both were codominant failures. This disparity was presumably attributable, in large part, to the presence of lateral branches.

Maples in the current study were noticeably larger than forest trees tested in previous studies, but the maximum bending moment at the point of failure was only marginally greater than the largest bending moments reported for forest trees (e.g., Papesch et al. 1997; Moore 2000). Part of this disparity can be explained by the difference in height of failure; the lever arm from which bending moment was calculated was naturally longer for trees that failed closer to the ground. The maximum bending moment at breast height, however, was more than twice the values from previous studies because maples tested in the current study were larger. This finding further illustrates the importance of defects (i.e., lateral branches and codominant stems) as a source of failure of shade trees.

\section{CONCLUSIONS}

This study was the first to test large shade trees by pulling them to failure, providing much-needed empiric data. In light of potential risk associated with failure of large shade trees and their importance to urban and suburban communities, results of this study are integral to developing better techniques to assess the risk of failure of shade trees. Arborists and urban foresters can use the results to quantify risk associated with codominant stems and should cautiously predict tree strength based on MOR of wood samples.

It was difficult to predict stress and slightly less difficult to predict bending moment at the point of failure for maples, and extrapolation from forest trees seems to be inappropriate given the importance of defects as points of failure on shade trees. Although species did not appear to influence results, the small sample size made it difficult to draw robust conclusions about the apparent lack of influence. The differences between stem failures and codominant failures merit further investigation. In particular, the importance of included bark as a synergist with codominant stems to weaken the structure of shade trees should be examined as well as investigations to determine the extent to which codominant stems are separate below the point of attachment.

Acknowledgments. We gratefully acknowledge the following individuals who contributed to this project: Daniel Pepin, Mike Geryk, Charlie Burnham, Alan Snow, Dawn Winkler, Ken Collette, Steve Orlik, Phil Campo, Melanie Joy, Kirk Stephens, Robert Rizzo, and Alex Schreyer. This project was funch \& Education Endownent Fund John Z. Duling grant from the TREE Fund.

\section{LITERATURE CITED}

Achim, A., J.-C. Ruel, B.A. Gardiner, G. Laflamme, and S. Meunier. 2004. Modelling the vulnerability of balsam fir forests to wind damage. Forest Ecology and Management 204:35-50.

Ancelin, P., B. Courbaud, and T. Fourcaud. 2004. Development of an individual tree based mechanical model to predict wind damage within forest stands. Forest Ecology and Management 203:102-121. 
ASTM (American Society of Testing Materials). 2000. Standard Methods of Testing Small Clear Specimens of Timber. D-143 Standard. West Conshohocken, PA.

Blackburn, P., J.A. Petty, and K.F. Miller. 1988. An assessment of the static and dynamic factors involved in windthrow. Forestry 61:29-43.

Brudi, E., and P. van Wassenaer. 2001. Trees and statics: Nondestructive failure analysis. In Smiley, E.T., and K.D. Coder (Eds.). Tree Structure and Mechanics Conference Proceedings: How Trees Stand Up and Fall Down. October 2001, Savannah, GA. International Society of Arboriculture, Champaign, IL. pp. 53-70.

Cutler, D.F., P.E. Gasson, and M.C. Farmer. 1990. The wind blown tree survey: Analysis of results. Arboricultural Journal 14:265-286.

Duryea, M.L., G.M. Blakeslee, W.G. Hubbard, and R.A. Vasquez. 1996. Wind and trees: A survey of homeowners after Hurricane Andrew. Journal of Arboriculture 22:44-50.

Fons, W.L., and W.Y. Pong. 1957. Tree Breakage Characteristics Under Static Loading; Ponderosa Pine. USDA Forest Service, Div. Forest Fire Research, Interim Tech. Rep. AFSWP-867. $51 \mathrm{pp}$

Francis, J.K. 2000. Comparison of hurricane damage to several species of urban trees in San Juan, Puerto Rico. Journal of Arboriculture 26:189-197.

Fraser, A.I. 1962. The roots and soil as factors in tree stability. Forestry 35:117-127.

Fraser, A.I., and J.B.H. Gardiner. 1967. Rooting and Stability in Sitka Spruce. Forestry Commission Bulletin No. 40. HMSO, London, U.K.

Fredericksen, T.S., R.L. Hedden, and S.A. Williams. 1993. Testing loblolly pine wind firmness with simulated wind stress. Canadian Journal of Forest Research 23:1760-1765.

Gardiner, B.A., H. Peltola, and S. Kellomaki. 2000. Comparison of two models for predicting the critical wind speeds required to damage coniferous trees. Ecological Modelling 129:1-23.

Gibbs, J.N., and B.J.W. Greig. 1990. Survey of parkland trees after the great storm of 16 October 1987. Arboricultural Journal 14:321-347.

Gilman, E.F. 2003. Branch-to-stem diameter ratio affects strength of attachment. Journal of Arboriculture 29:291-293.

Green, D.W., J.E. Winandy, and D.E. Kretschmann. 1999. Mechanical properties of wood. In Wood Handbook-Wood as an Engineering Material. Gen. Tech. Rep. FPL-GTR-113. WI, USDA Forest Service Forest Products Laboratory, Madison, WI. 463 pp.

Hannover, M., and J. Schaper. 2003. Wood properties of the Norway maple. Forst und Holz 58:695-696.

James, K.R., N. Haritos, and P.K. Ades. 2006. Mechanical stability of trees under dynamic loads. American Journal of Botany 93: 1361-1369.

Jim, C.Y., and H.H.T. Liu. 1997. Storm damage on urban trees in Guangzhou, China. Landscape and Urban Planning 38:45-59.

Kane, B.C.P., and H.D.P. Ryan. 2004. The accuracy of formulas used to assess strength loss due to decay in trees. Journal of Arboriculture 30:347-356

Kane, B.C.P., H.D.P. Ryan, and D.V. Bloniarz. 2001. Comparing formulae for assessing strength loss due to decay in trees. Journal of Arboriculture 27:78-87.

Lardner, T.J., and R.R. Archer. 1994. Mechanics of Solids. McGraw Hill, New York, NY. 802 pp.

Meunier, S., J.C. Ruel, G. Laflamme, and A. Achim. 2002. Comparative resistance of white spruce and balsam fir to overturning. Canadian Journal of Forest Research 32:642-652.

Miller, V.J. 1959. Crotch influence on strength and breaking point of apple tree branches. Proceedings of the American Society for Horticultural Science 73:27-32.

Milne, R., and P. Blackburn. 1989. The elasticity and vertical distribution of stress within stems of Picea sitchensis. Tree Physiology 5: 195-205.

Moore, J.R. 2000. Differences in maximum resistive bending moments of Pinus radiata trees grown on a range of soil types. Forest Ecology and Management 135:63-71.
Mortimer, M.J., and B.C.P. Kane. 2004. Hazard tree law in the United States. Urban Forestry and Urban Greening 2:208-215.

Nowak, D.J., and J.F. Dwyer. 2000. Understanding the benefits and costs of urban forest ecosystems. In Kuser, J.E. (Ed.). Handbook of Urban and Community Forestry in the Northeast. Kluwer Academic/ Plenum Publishers, New York, NY. pp. 11-25.

Nowak, D.J., J.C. Stevens, S.M. Sisinni, and C.J. Luley. 2002. Effects of urban tree management and species selection on atmospheric carbon dioxide. Journal of Arboriculture 28:113-122.

Oliver, H.R., and G.J. Mayhead. 1974. Wind measurements in a pine forest during a destructive gale. Forestry 47:185-194.

Papesch, A.J.G., J.R. Moore, and A.E. Hawke. 1997. Mechanical stability of Pinus radiata trees at Eyrewell Forest investigated using static tests. New Zealand Journal of Forestry Science 27:188-204.

Peltola, H. 2006. Mechanical stability of trees under static loads. American Journal of Botany 93:1501-1511.

Peltola, H., S. Kellomaki, A. Hassinen, and M. Granader. 2000. Mechanical stability of Scots pine, Norway spruce, and birch: An analysis of tree-pulling experiments in Finland. Forest Ecology and Management 135:143-153.

Peltola, H., S. Kellomaki, H. Vaisanen, and V.-P. Ikonen. 1999. A mechanistic model for assessing the risk of wind and snow damage to single trees and stands of Scots pine, Norway spruce, and birch. Canadian Journal of Forest Research 29:647-661.

Petty, J.A., and C. Swain. 1985. Factors influencing stem breakage of conifers in high winds. Forestry. 58:75-84.

Smiley, E.T. 2003. Does included bark reduce the strength of codominant stems? Journal of Arboriculture 29:104-106.

Smiley, E.T., and B.R. Fraedrich. 1992. Determining strength loss from decay. Journal of Arboriculture 18:201-204.

Smith, V.G., M. Watts, and D.F. James. 1987. Mechanical stability of black spruce in the clay belt region of northern Ontario. Canadian Journal of Forest Research 17:1080-1091.

Somerville, A.R. 1979. Root anchorage and root morphology of Pinus radiata on a range of ripping treatments. New Zealand Journal of Forestry Science 9:294-315

Terho, M., and A.M. Hallaksela. 2005. Potential hazard characteristics of Tilia, Betula, and Acer trees removed in the Helsinki City area during 2001-2003. Urban Forestry and Urban Greening 3:113-120.

Wood, C.J. 1995. Understanding wind forces on trees. In Coutts, M.P., and J. Grace (Eds.). Wind and Trees. Cambridge University Press, Cambridge, U.K. pp. 133-163.

Brian Kane (corresponding author)

University of Massachusetts-NRC

126 Holdsworth Hall

Amherst, MA 01003, U.S.

bkane@nrc.umass.edu

\section{Peggi Clouston}

University of Massachusetts-NRC

127 Holdsworth Hall

Amherst, MA 01003, U.S.

Résumé. Les arbres ornementaux peuvent blesser les gens et causer des dommages aux propriétés lorsqu'ils tombent. En dépit du risque potentiel de litiges coûteux qui survient lorsque des arbres tombent et causent des dommages, il n'y a pas d'étude qui a pu déterminer de manière empirique la chute des arbres ornementaux. Trente-quatre arbres ornementaux de trois espèces du genre Acer ont été tirés jusqu'au point de rupture dans une propriété de banlieue du Massachusetts. La charge maximum et la distance de bris ont été employées pour calculer le moment de flexion maximum; le stress au point de rupture a été calculé à partir du moment de flexion et des dimensions de la section 
transversale de la tige. Aucun arbre ne s'est déraciné; quant aux bris, ils ont été classés entre ceux provenant le long de la tige sur des branches latérales et ceux provenant du point d'attache entre des branches codominantes. Les bris de branches codominantes ont requis la moitié seulement de la valeur en stress par rapport aux bris de tiges elles-mêmes. De manière similaire, les bris de branches codominantes se produisaient à seulement $45 \%$ de la capacité de résistance du bois tandis que ceux des tiges se produisaient à $79 \%$ de la capacité. La prédiction du moment de flexion maximum à partir de données morphométriques de l'arbre était plus fiable que la prédiction du stress maximal. La prédiction du moment maximum de flexion et de stress a été comparée à des tests similaires sur des conifères forestiers. Ces découvertes ont des implications importantes en regard de l'évaluation du risque posé par un arbre.

Zusammenfassung. Schattenbäume können, wenn sie versagen, Menschen verletzen und Sachschäden verursachen. Trotz der potentiell kostenintensiven Rechtsstreite, die gelegentlich entstehen, wenn Schäden verursacht werden, gibt es keine Studien, die empirisch das Versagen von Schattenbäumen untersuchen. 24 Schattenbäume aus drei Species der Gattung Acer wurden auf einem suburbanen Gelände in Massachusetts bis zum Umfallen gezogen. Die maximale Last und Distanz des Versagens wurde verwendet, um den maximalen Biegemoment zu kalkulieren, der Stress am Versagenspunkt wurde kalkuliert aus dem Biegemoment und den Baumdurchmesser-Dimensionen. Kein Baum wurde entwurzelt und das Versagen wurde kategorisier in entweder des Stammes an einem lateralen Ast oder an der Anbindung eines kodominanten Stammes. Das Versagen von kodominanten Stämmen erforderte nur die Hälfte des Stresses als Einzelstämme. Vergleichbar traten die Versagen von kodominanten Stämmen bei nur $45 \%$ der Holzstärke auf, während Stammversagen bei $79 \%$ auftraten. Die Vorhersage des maximalen Biegemoments aus den morphometrischen Daten des Baumes war verlässlicher als die Vorhersage des maximalen Stresses. Die Ergebnisse wurden verglichen mit ähnlichen Tests an Koniferen. Die Resultate enthalten wichtige Implikationen in Verbindung mit der Risikobewertung bei Bäumen.

Resumen. Los árboles de sombra, si fallan, pueden lastimar y dañar las propiedades. A pesar del potencial por los costosos litigios que algunas veces se elevan cuando el árbol causa daño, no hay estudios que tengan investigado empíricamente la falla de árboles de sombra. Veinticuatro árboles de sombra de tres especies del género Acer fueron probados en una propiedad suburbana en Massachusetts. Se usó la carga máxima y la distancia para calcular el máximo del momento de doblamiento; el estrés en el punto de falla fue calculado del momento de doblamiento y las dimensiones de la sección trasversal del tallo. No se categorizaron los árboles dañados bien sea en la rama lateral o en la unión de la ramas codominantes. Las fallas de las ramas codominantes requirieron solamente la mitad del estrés de las fallas de los tallos. Similarmente, las fallas de las ramas codominantes ocurrieron en solamente $45 \%$ de resistencia de la madera, mientras que las fallas en los tallos ocurrieron en el $79 \%$ de la madera. La predicción del máximo momento de doblamiento de los datos morfométricos del árbol fue más real que la predicción del estrés máximo. La predicción del máximo momento de doblamiento y estrés fue más real para las fallas de los tallos que en las ramas codominantes. Los resultados son comparados a pruebas similares en bosques de coníferas. Los hallazgos tienen importantes implicaciones con respecto a la evaluación del riesgo en los árboles. 